\title{
Evolution of the Interest on Edible Insects
}

\author{
Nelida Lucia del Mastro \\ Instituto de Pesquisas Energeticas e Nucleares, IPEN/CNEN, São Paulo, Brazil
}

\author{
Email address: \\ nlmastro@ipen.br
}

\section{To cite this article:}

Nelida Lucia del Mastro. Evolution of the Interest on Edible Insects. American Journal of Biological and Environmental Statistics. Vol. 7, No. 2, 2021, pp. 52-56. doi: 10.11648/j.ajbes.20210702.13

Received: June 4, 2021; Accepted: June 18, 2021; Published: June 23, 2021

\begin{abstract}
Insects are being used as foods in both ancient and present days in different societies. A FAO report of 2013 reckoned that insect, farming in a that large-scale, would be the most effective way to addressed global food insecurity. At present nevertheless, there are poor knowledge on sustainably of farm insects and about species that would be best suited commercially. In the present work a tentative was made to describe the state of the art up to today on the subject of edible insects with emphasis on the important facts about them. In particular, special attention was given to Tenebrio molitor and Hermetia illucens, considered among the most promising insect larvae with extraordinary potential to be a food source alternative. The role that they can play when looking for more environmentally friendly alternatives for proteins and fats and the role of edible insects in the preservation of the environment were highlighted. A survey on the Web of Science data base was made in order to establish the evolution on the number of published articles about edible insects and in particular the two mentioned edible insects with time. it is worth mentioning that until the 1980 decade, the number of published articles on edible insects was very poor. In the mentioned data base, it was found that the first article on that subject was published on 1973. The amazing and increasing interest on experimental studies using edible insects in the last three decades correlate to the search for alternative sources of quality proteins and other important nutrients found in edible insects, besides the classical protein sources such as meat or to a less extent, plant proteins.
\end{abstract}

Keywords: Edible Insects, Novel Foods Sources, Food Nutrients, Sustainability of Food Sources, Tenebrio molitor, Hermetia illucens

\section{Introduction}

Human beings need eat protein in the diets for living. For much of the world's population, that means eating meat. Domestic mammal animals and birds are great sources of protein, but raising them consumes huge amounts of resources and has a major environmental impact. Livestock farming needs also enormous spaces of land, so it is an inductor to deforestation, employing a significant portion of valorous fresh water and producing some of the primary greenhouse gases in Earth's atmosphere [1]. For these reasons, there are a constant search for alternative sources of protein and other important nutrients, like essential fats, that can combine the world's nutritional needs with no damage to the planet. Among them surge three important sources: plant-based proteins, lab-grown meat and insects (Table 1).

It is called insect "any of numerous small invertebrate animals that are more or less obviously segmented and that include members of the class Insecta and others (as spiders, mites, ticks, centipedes, sowbugs) having superficial resemblance to members of Insecta. Technically insect is just a member of the class Insecta (as an ant, bee, fly) "' according to Webster's third New International Dictionary, Encyclopedia Britannica, Inc (1976).

It is considered that insects, both cooked and raw, are regularly part of the diet for about two billion people, following specificities of many nations and or ethnic groups.

According to U. N. Food and Agriculture Organization (FAO) there are more than 1,900 edible insect species on Earth. In spite of lack of data and information on insect supply and consumption, it is believed that around $10 \%$ of them have served as traditional foods among indigenous peoples and is part of the history from the point of view of human nutrition. 
Table 1. Comparison of animal protein sources.

\begin{tabular}{llll}
\hline Animal group & Species & Edible product & Protein content (g/100g fresh weight) \\
\hline Insects (row) & Locusts, rasshoppers & Larva & $14-18$ \\
& Locust, grasshoppers & Adult & $13-28$ \\
& Silkworm & Caterpillar & $10-17$ \\
& Palmwork beetles & Larva & $7-36$ \\
& Yellow mealworm & Larva & $14-25$ \\
& Crickets & Adult & $8-25$ \\
& Termites & Adult & $13-28$ \\
Cattle & & Beef (raw) & $19-26$ \\
Fish (raw) & Tilapia & & $16-19$ \\
& Mackerel & & $16-28$ \\
Crustaceans & Lobster & & $17-19$ \\
& Shrimp & & $13-27$ \\
\hline
\end{tabular}

Source: adapted from Akhtar \& Isman, 2018 [2].

Following FAO estimate, around 36 African countries can be considered entomophagous (including here the high diversity in species as well as metamorphological life-stages), as are 23 in the Americas, 29 in Asia, and even 11 in Europe. The top edible insect groups are: beetles (mealworms, the larval form of a particular species), butterflies and moths (during their larval and pupal stages), bees and wasps (in immature stages), ants, grasshoppers, crickets, and locusts (the most consumed type of insect) [3].

In 2013, a United Nations Food and Agriculture Organization (FAO) report reckoned that insect, farming in a that large-scale, would be the most effective way to addressed global food insecurity. In the last decade, some companies enter in the market offering processes to recover solid proteins and fat from black soldier fly, and other edible insects like crickets, grasshoppers, ants, mealworms, cicadas, moths, beetles and cockroaches.

The European Commission (EU) recently approved the sale of the first insect for human consumption. Dried yellow mealworm can now be sold across the 27-nation bloc, after a decision from EU governments and a food safety assessment. EU officials suggest this insect could be used as a protein boost for cookies, pasta or baked goods. The market for edible insects is set to reach $€ 3$.8bn by 2027 , according to one report earlier this year. In a report published Jan. 13, the European Food Safety Authority, or EFSA, declared that "dried yellow mealworm, the larval form of a beetle, is safe for human consumption". Authorities consider an important assessment of a proposed insect-derived food product and "part of the EU's effort to regulate novel foods," which popularity as an alternate source of protein is growing, thanks to many factors among them search for more sustainable protein sources beyond meat. The Standing Committee on Plants, Animals, Food and Feed (Novel Food and Toxicological Safety section), which is composed of representatives of all EU countries and chaired by a European Commission representative, has given, on 3rd May, 2021, "a favorable opinion on the draft legal act authorizing the placing on the market of dried yellow mealworm, as a novel food'.

The yellow mealworm is the larvae of the beetle Tenebrio molitor. This "novel food" is intended to be used as a whole, dried insect in the form of snacks or as a food ingredient, in a number of food products (https://ec.europa.eu/food/safety/novel_food/authorisations/a pproval-first-insect-novel-food_en).

Although insects are regular foods in many places around the world, many western consumers have still concern about that. The tendency, however, is they will soon think otherwise. Presently the main reasons to turn edible insects in a regular food ingredient is that they are palatable, sustainable, and healthy. Chitin, found mainly in insects, snails, shrimps and even in the cell walls of mushrooms and other fungi, is a naturally occurring fiber similar to cellulose, and act as prebiotic. Roasted mealworms, for instance, can be a good snack as they are crunchy, filled up with flavor and spices, rich in protein and vitamins.

\section{Benefits of Edible Insects in Human Diets}

Imathiu in 2020 [4] synthesized the benefits and risks of edible insects when used as food (usage as feed was also studied by, for instance, Verbeke et al., 2015 [5]). Although the 4 stages of insects (eggs, larvae, pupa, and adult stage) are edible, larvae are most often consumed. Insects are rich in nutrients. Several laboratories analyzed the content of protein, fat, carbohydrates, ash, fiber, minerals, amino acids, and fatty acids in adult cricket (Gryllodes sigillatus), larvae of mealworm (Tenebrio molitor), and adult locust (Schistocerca gregaria). They found that the protein content ranged from 52.35 to $76 \%$. The fat percentage was in the range of 12.97 $24.7 \%$. Energy contribution varied from 1821 to $1896 \mathrm{~kJ} / 100 \mathrm{~g}$. Their amino acid profile was compared with the WHO/FAO/UNU Pattern [6][7]. Other authors found also that insects are important source of minerals [8], being the mineral content of magnesium, copper, iron, and zinc comparable to recommended daily intakes (mg/day) supplying amounts of protein, fat, vitamins, and minerals comparable to those of meat [9]. They can improve human gut microbiota, can be considered a source of livelihood and rearing edible insects brings enormous environmental benefits in comparison with the production of other protein sources as insects require less land and water to be farmed.

On the other hand, edible insect consumption presents 
several challenges in terms of food safety (presence of pathogenic microorganisms or parasites), acceptability, for instance in a recent study made on acceptability of edible insects by Americans [10] and potential hazards like the presence of allergens, pesticides residues, mycotoxins, antinutrients or heavy metals. For instance, those with prawn and dust mite allergies are likely to suffer allergic reactions to the Tenebrio molitor larvae, such as those allergics to crustaceans. Food safety of edible insects can easy be overcome using radiation sterilization as proposed few years ago by Del Mastro in 2016 [11].

It is still required to emphasizes the importance of the nutritional and environmental aspects of insects among Western media and academia [12].

In the African continent, although it is common to eat insects, several challenges still remain on their commercialization. It is a major challenge for the continent to develop proper technologies of farming. Some authors consider the creation of a sustainable industry for large scale insect production as a good strategy. It means being put into practice optimum harvesting and mass rearing keeping proper handling practices [13].

Insects are being used for thousands of years as foods in China [14]. Different edible insects, from the many species found in China are consumed in different regions depending on local food preferences. Many common edible insects belong to Lepidoptera, Coleoptera and Hymenoptera. Just to mention some important edible insects in China: ant species Polyrhachis vicina Rogen, honey bee (Apis cerana Fabr. and Apis mullifera L.) and its products and the larvae of Bombycis and the bamboo weevil. Luo considered that the commercial exploitation must be accepted provided a controlled production was made without disturbing the natural balance.

In Japan, like in China, some insects are consumed as food but also for traditional medicine purposes. In the list of Japanese people preferences is possible to found: a grasshopper, Oxya yezoensis or O. japonica [15], mixtures of river-living insect larvae, the larvae and pupae of a wasp, Vespula lewisi, pupae and female adults after oviposition of Bombyx mori, larvae of the dobsonfly and Protohermes grandis (Neuroptera) that has been consumed as a traditional medicine

In Mexico, insects were eaten since pre-Hispanic times being an important source of protein for Mexicans, and a variety of species continue to be consumed to present times. According to Tang (2014) the most tasteful insects and bugs to eat in Mexico are: "gusanos" (maguey worms), j"umiles" (stink bugs), "chicatanas" (giant winged ants), "escamoles" (ant larvae), "ahuatle" (water-fly eggs), "cuchamás" (green caterpillars), "chapulines" (grasshoppers), "alacránes" (scorpions), "libélulas" (dragonflies) and "escarabajos" (beetles) [16].

Katayama et al. in 2009 [17] proposed the use edible insects for feeding astronaut crews considering the nutritive and palatable aspects and the possibility of space agriculture.

Several studies appeared recently on key aspects of the acceptance of edible insects: perceptions, attitudes, willingness and propensity to consume insects-based food in the regular diet [18-20].

\section{Black Soldier Fly and Mealworms}

Together with plant-based protein, edible insects have increased demand around the world. Thanks to great nutritional value and environmentally friendly raising conditions, this demand, particularly for edible insects, is only expected to grow in the future.

Tenebrio molitor and Hermetia illucens are both likely to success as edible insects for the future mainly for the role that they can play on the environment when looking for more environmentally friendly alternatives for protein and fats. The Tenebrio molitor insect larvae, yellow mealworms, consumes polystyrene according to a work of Zielinska et al. in 2021 [21], biodegrades polyvinyl chloride (PVC) as showed by Bo-Yu et al., in 2020 [22], biodegrades vulcanized SBR and tire crumb according to Aboelkheir et al., [23], and biodegrades polypropylene (PP) via gut-microbe-dependent depolymerization as reported recently by Shan-Shan et al., [24]. On the other hand, mealworm oil can be converted to biodiesel [25].

Hermetia illucens known as black soldier fly, offers benefits to the environment as it is a recycler, decomposer, and feeds on manure, compost, and other organic wastes. Then, black soldier flies have a huge potential in biowaste treatment [26]. As helping manage manure, the larvae convert the manure's nutrients into protein and fat. Simultaneously, the larva prevents the development of pest flies (https://aggie-horticulture.tamu.edu/galveston/beneficials/bene ficial-51_black_soldier_fly.htm).

The black soldier fly is being considered a super fly that could feed us and a superstar in terms of protection of environment, consume plastic and produce fuel. Farming them could save the world, considers a report from Forbes (https://www.forbes.com/sites/ariellasimke/2019/12/01/black -soldier-flies-are-the-new-superstars-of-sustainable-aquacultu $\mathrm{re} /$ ?sh=62f64ec53ac1).

\section{Evolution of Interest on Edible Insects}

Until the twentieth century very few papers on edible insects had been published according to Web of Science data base (Figure 1). The earliest papers registered in that database appeared in 1973, 1980 and 1983 [27-29].

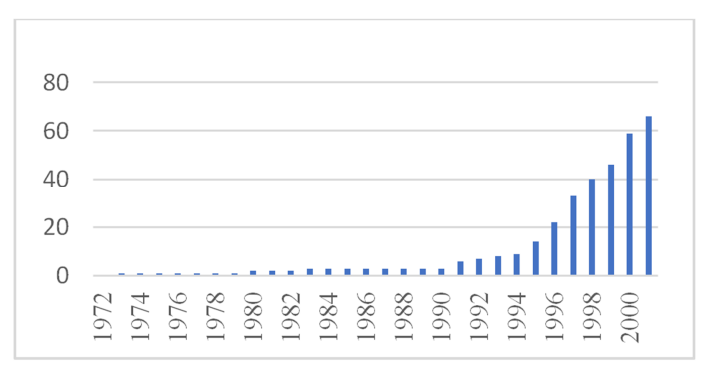

Figure 1. Number of published articles on edible insects up to 2000. 
The interest on the study on edible insects start to increase almost exponentially in the three last decades (Figure 2).

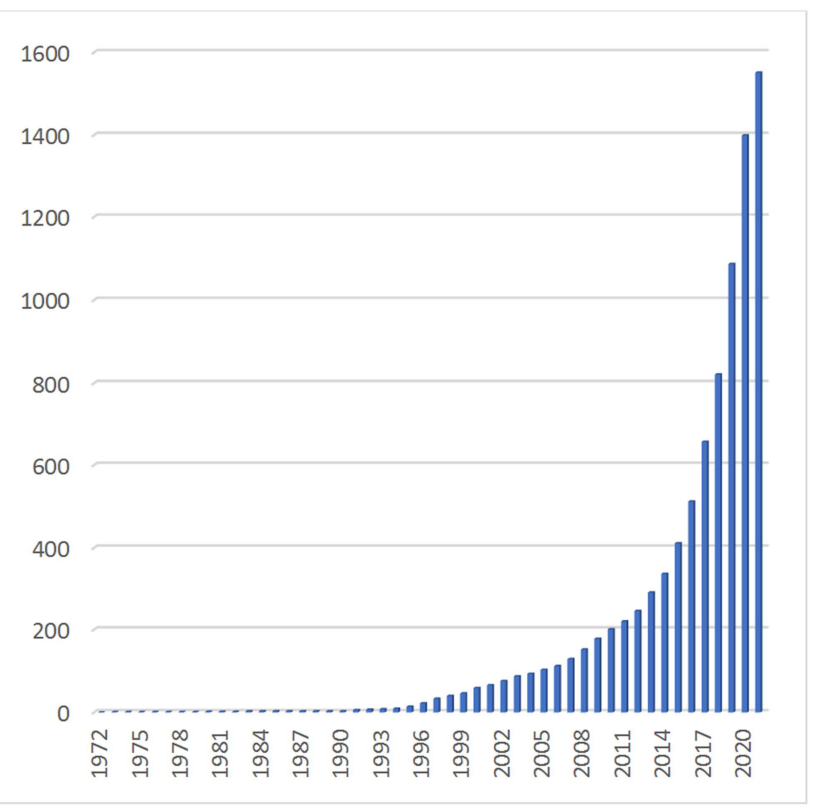

Figure 2. Number of published articles on edible insects (up to May 26, 2021).

The increasing academic interest on Tenebrio molitor or Hermetia illucens is evident analyzing the number of published papers using their names as tags. Figure 3 displays the evolution on the number of published articles starting from 1950 up to 2020. It is notorious that while Tenebrio molitor is being increasingly studied since decades, the interest on Hermetia illucens is much more recent.

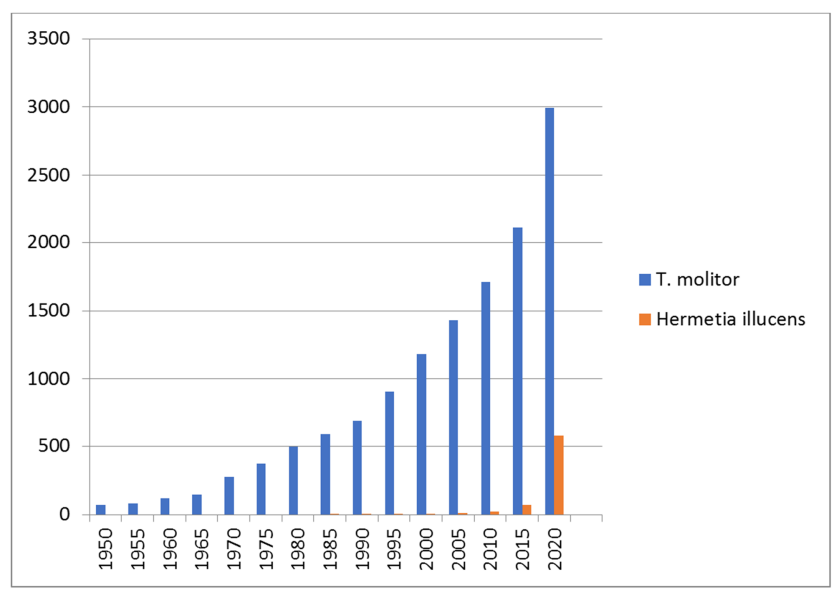

Figure 3. Number of published articles on two important edible insects, using as tags the words Tenebrio molitor and Hermetia illucens, from 1950 to 2020.

\section{Concluding Remarks}

As pointed up by FAO in 2013 [30] and also recently by Ordoñez-Araque et al. [31], among other authors, it seems that edible insects are the most promising food alternative in terms of protection of the environment. The extraordinary nutritional characteristics must be considered together with issues on environment, social and governance (ESG) strategies. Also, the possibility of modify fatty acids profile of Tenebrio molitor and Hermetia illucens larvae by means of proper substrates raises promising expectations [32]. The increase on the number of published papers, shown in the present work, is an evidence of the increasing importance of sustainability of food sources given by academia, the consumer and the industry as well.

\section{References}

[1] Bebernes, M. (2020) Are insects the food of the future? (https://news.yahoo.com/are-insects-the-food-of-the-future-16 1522789.html?soc_src $=$ hl-viewer\&soc_trk $=$ ma.)

[2] Akhtar, Y. \& Isman, M. B. (2018). 10 - Insects as an Alternative Protein Source, Editor (s): Rickey Y. Yada, In: Woodhead Publishing Series in Food Science, Technology and Nutrition, Proteins in Food Processing (Second Edition), Woodhead Publishing, p. 263-288. DOI: 10.1016/B978-0-08-100722-8.00011-5.

[3] Holland, J. S. (2013). UN Urges Eating Insects; 8 Popular Bugs to Try. National Geographic, May 14, 2013.

[4] Imathiu, S. (2020). Benefits and food safety concerns associated with consumption of edible insects. NFS Journal, 18: $1-11$.

[5] Verbeke, W.; Spranghers, T.; De Clercq, P.; De Smet, S.; Sas, B.; Eeckhout, M. (2015). Insects in animal feed: Acceptance and its determinants among farmers, agriculture sector stakeholders and citizens. Animal Feed Science and Technology, 204: 72-87. DOI: 10.1016/j.anifeedsci.2015.04.001.

[6] World Health Organization/Food and Agriculture Organization/United Nations University (2007). Protein and Amino Acid Requirements in Human Nutrition Report of a Joint WHO/FAO/UNU Expert Consultation. WHO Technical Report Series no. 935. Geneva: WHO.

[7] Zielińska, E., Baraniak, B., Karaś, M. Rybczyńska, K.; Jakubczyk, A. (2015). Selected species of edible insects as a source of nutrient composition, Food Research International, 77 (30: 460-466. DOI: 10.1016/j.foodres.2015.09.008.

[8] Melo, V.; Reyes, J.; Castrejon, E.; Salas, J.; Nogueda, N. (2006). Metals in three species of edible insects in Mexico. In: Ions in Biology and Medicine Series, v. 9, p. 481-. Editors: Alpoim, M. C; Morais, P. V. 9th International Symposium on Metal Ions in Biology and Medicine, Lisbon, Portugal, May 21-24, 2006.

[9] Baiano, A. (2020). Edible insects: An overview on nutritional characteristics, safety, farming, production technologies, regulatory framework, and socio-economic and ethical implications. Trends in Food Science \& Technology, 100: 35-50. DOI: 10.1016/j.tifs.2020.03.040.

[10] Higa, J. E.; Ruby, M. B.; Rozin, P. (2021). Americans' acceptance of black soldier fly larvae as food for themselves, their dogs, and farmed animals. Food Quality and Preference, 90, article number $104119 . \quad$ DOI: 10.1016/j.foodqual.2020.104119.

[11] Del Mastro, N. L. (2016). Potential Use of Irradiation on Edible Insects. Academia Journal of Agricultural Research, 4 (6) DOI: 10.15413/ajar.2016.0600. 
[12] DeFoliart, G. R. (1997). An overview of the role of edible insects in preserving biodiversity. Ecology of Food and Nutrition, $\quad 36 \quad(2-4): \quad 109-132 . \quad$ DOI: 10.1080/03670244.1997.9991510.

[13] Niassy, S., Musundire, R., Ekesi, S. and van Huis, A. (2018). Edible insect value chains in Africa. Journal of Insects as Food and Feed, 4 (40): 199-201.

[14] Luo, Z. Y. Insects as food in China. (1997). Ecology of Food and Nutrition, 36 (2-4): 201-207.

[15] Mitsuhashi, J. (1997). Insects as traditional foods in Japan. Ecology of Food and Nutrition, 36 (2-4): 187-199. DOI: 10.1080/03670244.1997.9991514.

[16] Tang P. (2014). The 10 tastiest insects and bugs in Mexico. Lonely Planet (https://www.lonelyplanet.com/articles/the-10-tastiest-insectsand-bugs-in-mexico access: June 17, 2021.

[17] Katayama, N.; Yoshimura, T.; Baba, K.; Yamashita, M. (2009). Insects for Space Agriculture and Sustainable Foods Web on Earth, In: Ed.: Kurmaz, S., Ince, F., Onbasioglu, S., Basturk, S. RAST 2009: Proceedings of the 4th International Conference on Recent Advances in Space Technologies, Istanbul, Turkey, Jun 11-13, 2009. DOI: 10.1109/RAST.2009.5158252.

[18] Florenca, S. G.; Correia, P. M. R.; Costa, C. A. et al. (2021). Edible Insects: Preliminary Study about Perceptions, Attitudes, and Knowledge on a Sample of Portuguese Citizens. Foods, 10 (4), article number: 709.

[19] Iseppi, L., Rizzo, M., Gori, E. et al. (2021). Rasch Model for Assessing Propensity to Entomophagy. Sustainability, 13 (8), article number 4346.

[20] Khalil, R.; Kallas, Z.; Haddarah, A. et al. (2021). Impact of COVID-19 Pandemic on Willingness to Consume Insects-based Food Products in Catalonia. Foods, 10 (4), article number 805 .

[21] Zielinska, E.; Zielinski, D.; Jakubczyk, A.; Kara, M.; Pankiewicz, U.; Flasz, B.; Dziewięcka, M.; Lewicki, S. (2021). The impact of polystyrene consumption by edible insects Tenebrio molitor and Zophobas morio on their nutritional value, cytotoxicity, and oxidative stress parameters. Food Chemistry, 345, article number 128846, DOI: 10.1016/j.foodchem.2020.128846.

[22] Bo-Yu Peng; Zhibin Chen; Jiabin Chen; Huarong Yu Xuefei Zhou,; Craig S. Criddle; Wei-Min Wu; Yalei Zhang. (2020). Biodegradation of Polyvinyl Chloride (PVC) in Tenebrio molitor (Coleoptera: Tenebrionidae) larvae. Environment International, 145, article number 106106, DOI: 10.1016/j.envint.2020.106106.
[23] Aboelkheir, M. G.; Visconte, L. Y.; Oliveira, G. E.; Toledo Filho, R. D.; Souza, F. G. (2019). The biodegradative effect of Tenebrio molitor Linnaeus larvae on vulcanized SBR and tire crumb. Science of The Total Environment, 649: 1075-1082. DOI: 10.1016/j.scitotenv.2018.08.228.

[24] Shan-Shan Yang; Meng-Qi Ding; Lei He; Chun-Hong Zhang; Qing-Xiang Li; De-Feng Xing; Guang-Li Cao; Lei Zhao; Jie Ding; Nan-Qi Ren; Wei-Min Wu. (2021). Biodegradation of polypropylene by yellow mealworms (Tenebrio molitor) and superworms (Zophobas atratus) via gut-microbe-dependent depolymerization, Science of The Total Environment, 756, article number 144087, DOI: 10.1016/j.scitotenv.2020.144087.

[25] Mariod, A. A.; Mirghani, M. E. S.; Hussein, I. (2017) Chapter 50 - Tenebrio molitor Mealworm, Editor (s): Abdalbasit Adam Mariod, Mohamed Elwathig Saeed Mirghani, Ismail Hussein, Unconventional Oilseeds and Oil Sources. Academic Press, p. 331-336. DOI: 10.1016/B978-0-12-809435-8.00050-0.

[26] Mertenat, A.; Diener, S.; Zurbrugg, C. (2019). Black Soldier Fly biowaste treatment - Assessment of global warming potential. Waste Management, 84: 173-181.

[27] Meyer-Rochow, V. B. (1973). Edible insects in three different ethnic groups of Papua and New Guinea. The American Journal of Clinical Nutrition, 26 (6): 673-677. DOI: 10.1093/ajen/26.6.673.

[28] Legner, E. F. \& Pelsue, FW. (1980). Bioconversion - tilapia fish turn insects and weeds into edible protein. California Agriculture, 34 (11): 13-14.

[29] Gope, B. \& Prasad, B. (1983). Preliminary observation on the nutritional-value of some edible insects of Manipur. Journal of Advanced Zoology, 4 (1): 55-61.

[30] Van Huis, A., Van Itterbeeck, J., Klunder, H., Mertens, E., Halloran, A., Muir G., Vantomme, P. (2013). Edible insects: future prospects for food and feed security. FAO Forestry Paper 171, FAO, Rome, 2013. ISBN 978-92-5-107595-1.

[31] Ordoñez-Araque, R.; Egas-Montenegro, E.; Ordoñez-Araque, R.; Egas-Montenegro, E. (2021). Edible insects: A food alternative for the sustainable development of the planet. International Journal of Gastronomy and Food Science, 23, article number: 100304, DOI: 10.1016/j.ijgfs.2021.100304.

[32] Lawal, K. G.; Kavle, R. R.; Akanbi, T. O.; Mirosa, M.; Agyei, D. (2021). Enrichment in specific fatty acids profile of Tenebrio molitor and Hermetia illucens larvae through feeding. Future Foods 3, article number 100016. 